\title{
Wagon Chassis Frame Design with Adaptable Loading Platform
}

Pavol Št’astniak

Faculty of Mechanical Engineering, University of Žilina. Univerzitná 8215/1, 01026 Žilina. Slovak Republic. E-mail: pavol.stastniak@fstroj.uniza.sk.

The paper present the structural design of freight wagon chassis frame with adaptable loading platform with regard to the safe operation and assessment of the properties by the calculation methods of simulation analysis. 3D model of wagon was created in a computer program PTC/Creo. Wagon chassis frame was subjected to the static and dynamic analysis in programs ANSYS and ADAMS/Rail. On the basis of computer aided simulation analysis was optimized the frame of the wagon. This wagon chassis frame will be able to offer even more capacity and utilize less resources and energy than current wagons for intermodal transport.

Keywords: Freight Wagon, Adaptable Platform, Simulation Analysis.

\section{Acknowledgement}

The work was supported by the Scientific Grant Agency of the Ministry of Education of the Slovak Republic and the Slovak Academy of Sciences in project No. 1/0347/12: "Railway wheel tread profile wear research under the rail vehicle in operation conditions simulation on the test bench", project No. 1/0383/12: "The rail vehicle running properties research with the help of a computer simulation." and the project No. APVV-0842-11: "Equivalent railway operation load simulator on the roller rig".

\section{Research-Educational Centre of Rail Vehicles (VVCKV)}

\section{References}

[1] VEL-WAGON Consortium (2011). Devilerable Report 1.1: State of the art and concept drafting.

[2] FABIÁN, P., GERLICI, J., MAŠEK, J., MÁRTON, P. (2013). Versatile, efficient and long wagon for intermodal transport in Europe. In: Communications: scientific letters of the University of Žilina. ISSN 1335-4205. Vol. 15, no. 2, p. 118-123.

[3] VEL-WAGON Consortium (2012). Deliverable Report 2.1: Intermodal application of Wel-Wagon.

[4] FABIÁN, P., GERLICI, J., MAŠEK, J., MÁRTON, P. (2013). Development of a new wagon for intermodal freight transport. In: EURO - ŽEL 2013: 21st international symposium "Recent challenges for European railways": symposium proceedings: 4th-5th June 2013, Žilina, Slovak Republic. Brno: Tribun EU, 2013. ISBN 978-80-263-03800. CD-ROM, p. 298-306.

[5] ŠŤASTNIAK, P., HARUŠINEC, J., GERLICI, J., LACK, T. (2012). Containers Transport Wagons Design (In Slovak). In: Dynamics of rigid and deformable bodies, Ústi nad Labem, Czech Republic: University J. E. Purkyně. ISBN 978-80-7414-510-0. CD-ROM, [7] p.

[6] ŠŤASTNIAK, P., HARUŠINEC, J., GERLICI, J., LACK, T. (2013). Railway vehicles design solutions for intermodal transport (In Slovak). In: Computational and experimental methods in applied mechanics I. Ústi nad Labem, Czech Republic: University J. E. Purkyně. ISBN 978-80-7414-609-1. p. 167-172.

[7] ŠŤASTNIAK, P., HARUŠINEC, J., GERLICI, J., LACK, T. (2014). Structural design of long freight railway wagon with variable use of loading space. In: Dynamics of rigid and deformable bodies, Ústi nad Labem, Czech Republic: University J. E. Purkyně. ISBN 978-80-7414-749-4. CD-ROM, [8] p.

[8] DIŽO, J. (2014). The freight wagon analysis using computer simulation. In: EURO - ŽEL 2014: 22nd international symposium "Recent challenges for European railways": symposium proceedings: 3rd-4th June 2014, Žilina, Slovak Republic. Brno: Tribun EU, 2014. ISBN 978-80-263-0700-6. CD-ROM, p. 44-51.

[9] DIŽO, J. (2015). Evaluation of Ride Comfort for Passengers by Means of Computer Simulation. In: Manufacturing Technology: Journal for science, research and production. ISSN 1213-2489. Vol. 15, No. 1, p. 8-14.

[10]BLATNICKÝ, M. (2014). Efficiency of usage of methods to resolve problems in mechanics (in Slovak). In: $D y$ namics of rigid and deformable bodies, Ústi nad Labem, Czech Republic: University J. E. Purkyně. ISBN 978-807414-749-4. CD ROM, [11] p. 
[11]ŠŤASTNIAK, P., HARUŠINEC, J. (2013). Computer Aided Simulation Analysis for Computation of Modal Analysis of the Freight Wagon. In: Communications: scientific letters of the University of Žilina. ISSN 1335-4205. Vol. 15 , no. 4, p. 73 - 79.

[12]HARUŠINEC, J., ŠŤASTNIAK, P., DIŽO, J. (2013). Calculations and Simulations in the Rail Vehicle Constructions Development (In Slovak). In: Technológ, University of Žilina, EDIS - Žilina University Publisher. ISBN 1337-8996, p. 239 - 244.

[13] ŠŤASTNIAK, P., HARUŠINEC, J. (2014). Simulation analysis of selected parameters by the development of nonstandard freight wagon. In: Experimental and Computational Methods, I. international conference for young scientists, Ústi nad Labem, Czech Republic: University J. E. Purkyně. ISBN 978-80-7414-725-8. CD-ROM, [8] p.

[14]ONDROVÁ, Z., GERLICI, J., LACK, T. (2008). Dinamic simulation analysis of a railway vehicle running on a real track. In: Dynamics of rigid and deformable bodies, Ústi nad Labem, Czech Republic: University J. E. Purkyně. ISBN 978-80-7414-030-3. p. 133-138.

[15] GERLICI, J., LACK, T. (2007). Methods for vehicle vibration analysis in time domain. In: Prace Naukowe. Transport. ISSN 1230-9265. Vol. 63, p. 71-81.

[16]GERLICI, J., LACK, T. (1997). Systems with concentrated masses dynamics analysis (in Slovak). In: Current problems in rail vehicles: 13. International Conference. Pardubice: University of Pardubice. ISBN 80-7194-1050. p. 263-271.

[17]SVOBODA, M., SKOČILAS, J., SOUKUP, J. (2011). Analysis of vertical vibration of mechanical system. In: Dynamical systems. Analytical /Numerical Methods, Stability, Bifurcation and Chaos. pp. 261 - 268. Department of Automation and Biomechanics. Polytechnika Lodž.

[18]SKOČILAS, J., SKOČILASOVÁ, B., SOUKUP, J. (). Determination of the rheological properties of thin plate under transient vibration. Latin American Journal of Solids and Structures. Brasil society for mechanics and engineering. ISSN 1679-7817 (print), 1679-7825 (online).

[19]NANGOLO, F. N., SOUKUP, J., SVOBODA, M. (2012). Modeling of vertical dynamic response of railway vehicle system with experimental validation. In: Machine Modeling and Simulation, pp. 295- 302, Polytechnika Poznaňska, Rokosovo, Poland. ISBN 978-83-923315-2-0. 